\title{
Effect of the Use of Metakaolin Artificial Lightweight Aggregate on the Properties of Structural Lightweight Concrete
}

\author{
Risdanareni, P..$^{1 *}$, Choiri, A.A. ${ }^{1}$, Djatmika, B. ${ }^{1}$, and Puspitasari, P. ${ }^{2}$
}

\begin{abstract}
This paper investigates the effect of using metakaolin Artificial Lightweight Aggregates (ALWA) as a substitute for coarse aggregates to produce structural lightweight concrete. A combination of $10 \mathrm{M} \mathrm{NaOH}$ solution and sodium silicate solution was used as alkali activator. The ratio between the metakaolin binder and the alkali activator used in producing metakaolin ALWA is $48 \%: 52 \%$, by mass. It is shown that metakaolin ALWA has higher abrasion and water absorption, and lower bulk density values compared to normal aggregates. To determine the effect of using metakaolin ALWA as coarse aggregates in concrete, three variations of ALWA dosages were used, i.e. $0 \%, 50 \%$, and $100 \%$ of the total coarse aggregates, by volume. The results show that the compressive strength of concrete decreased along with the increase of ALWA content in the mixture. However, concrete using 100\% ALWA as coarse aggregates meets the requirements of compressive strength and density of structural light weight concrete.
\end{abstract}

Keywords: ALWA; compressive strength; concrete density; geopolymer; lightweight concrete.

\section{Introduction}

Indonesia is a country in Asia that is prone to earthquake [1]. Based on data from Team for Revision of Seismic Hazard Maps of Indonesia in 2010, the financial loss incurred by the nation due to this natural disaster has reached trillions of Rupiahs for rehabilitation and reconstruction [2]. In order to minimize the amount of loss, the earthquake's load should be reduced. One promising method on minimizing earthquake hazards to buildings is by reducing the weight of the building, since the magnitude of the seismic force is directly proportional to the weight of the building [3]. Applying lightweight concrete with a density of $1100 \mathrm{~kg} / \mathrm{m}^{3}$ as a replacement of conventional concrete is one way to reduce the weight of structural and non-structural components of buildings.

Based on the classification of lightweight concrete according to the level of compressive strength and aggregate type by Mindess and Young [4], lightweight aggregate concrete using artificial lightweight aggregate (ALWA) or lightweight coarse sintered fly ash and foamed slag aggregates can produce compressive strength values of 17-41 $\mathrm{MPa}$ with a density range of $1500-2000 \mathrm{~kg} / \mathrm{m}^{3}$ [4].

\footnotetext{
${ }^{1}$ Department of Civil Engineering, Faculty of Engineering, State University of Malang, Malang, INDONESIA.

${ }^{2}$ Department of Mechanical Engineering, Faculty of Engineering, State University of Malang, Malang, INDONESIA.

*Corresponding author; Email: puput.risdanareni.ft@um.ac.id

Note: Discussion is expected before November, $1^{\text {st }} 2017$, and will be published in the "Civil Engineering Dimension", volume 20, number 1, March 2018.

Received 25 August 2017; revised 01 September 2017; accepted 11 September 2017.
}

Thus, it is included in the category of lightweight structural concrete because the compressive strength is not less than $17 \mathrm{MPa}$. One of the alternative materials that serves potentially as the basic ingredient of ALWA is metakaolin. Metakaolin is a material resulting from the calcination of kaolin at a certain temperature. The Ministry of Energy and Mineral Resources (KESDM) in 2015 stated that the availability of kaolin in Indonesia was approximately more than one billion tons with a low utilization rate [5].

Triani et al. and Risdanareni et al.'s study on the use of metakaolin as a raw material for manufacturing geopolymer paste found that the compressive strength of metakaolin-based geopolymer paste reached more than $42 \mathrm{MPa}$ [6,7]. Based on the chemical composition of metakolin, the total amount of $\mathrm{SiO}_{2}+\mathrm{Al}_{2} \mathrm{O}_{3}+\mathrm{Fe}_{2} \mathrm{O}_{3}$ in metakaolin is very high, i.e. $93.99 \%$, thus it can be categorized as natural pozzolan of class N [6]. Subsequent research conducted by Aineto et al. on the manufacture of metakolin ALWA found that sintering at a certain temperature was effective to reduce the unit weight of ALWA [8].

Further, Lauw and Buen showed that the transition from normal to lightweight concrete occurred after $50 \%$ of the total volume of the coarse aggregates in concrete was replaced by styrofoam ALWA [9]. Referring to this research finding, the present research investigated three coarse aggregate replacement percentages by metakaolin ALWA, i.e. 0\%, $50 \%$, and $100 \%$ from the total volume of coarse aggregate, to determine the optimum dosage of ALWA as a substitute of coarse aggregates in manufacturing lightweight structural concrete. 


\section{Materials and Method}

The research was conducted in the Materials Testing Laboratory and Structure Laboratory at the Faculty of Engineering, Universitas Negeri Malang, and at a ceramic factory in Malang. Metakaolin was obtained by combusting kaolin at temperature of $800^{\circ} \mathrm{C}$. Next, the consistency and setting time were evaluated to ensure that the metakaolin was reactive. The ALWA grains were processed using a pan granulator with a composition ratio of metakaolin to alkaline activator of $52 \%: 48 \%$, by mass. This composition was determined from twelve trials that have been performed.

In this study, the alkaline activator solution was a mixture of $\mathrm{Na}_{2} \mathrm{SiO}_{3}$ (sodium silicate) and $10 \mathrm{M}$ $\mathrm{NaOH}$ (sodium hydroxide) solution. The ratio of $\mathrm{Na}_{2} \mathrm{SiO}_{3}$ to $\mathrm{NaOH}$ solution was $2: 1$, by mass. The mass ratio between metakaolin and alkali activator solution in producing lightweight aggregate was determined during the manufacturing process. The experimental data on obtaining the proportion between metakaolin and alkali activator solution is presented at Table 1, while aggregate manufacture process is presented at Figure 1.

Manufacturing metakaolin ALWA was performed using a granulator pan. The slope angle of the granulator pan used in this research was $45^{\circ}$. After setting-up the granulator pan, metakaolin was poured into the granulator pan, while the alkali activator solution was added gradually. The process of adding alkali activator solution into the mixture was stopped when the paste has formed aggregate granules of 1 to $2 \mathrm{~cm}$ in diameter, and the surface of metakaolin granules aggregates appeared slightly wet.

ALWA granules were dried in an oven for 24 hours to remove the water content. Then, they were burned at a temperature of $600{ }^{\circ} \mathrm{C}$ for 6 hours to create pores in metakaolin ALWA, in order to obtain a bulk density of less than $1100 \mathrm{~kg} / \mathrm{m}^{3}$.

The specimens in this research were 54 concrete cylinders of $7.5 \mathrm{~cm}$ diameter and $15 \mathrm{~cm}$ height, produced using two different types of coarse aggregates, i.e. metakaolin ALWA (AM) and normal coarse aggregates (AN). The amount of metakaolin ALWA was varied from $0 \%, 50 \%$, and $100 \%$ of the total volume of coarse aggregates required to produce concrete. Concrete specimens using only normal coarse aggregates was assigned as the control group, to be compared with concrete specimens made using 50\% and 100\% metakaolin ALWA. The specimens are described in detail in Table 2, while the mix design of concrete specimens is presented in Table 3.

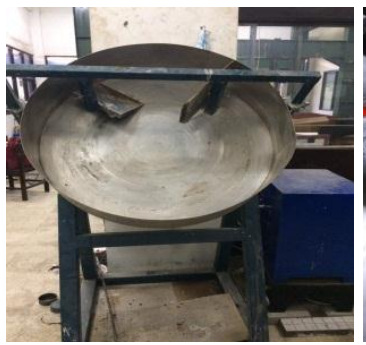

(a)

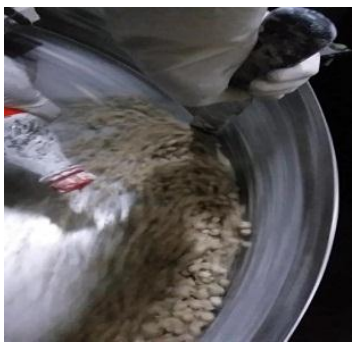

(b)

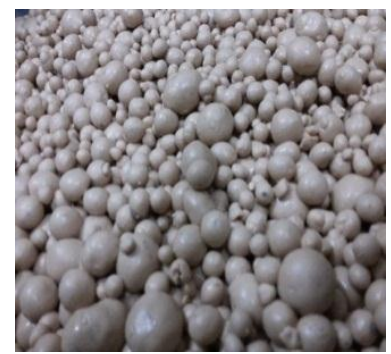

(c)

Figure 1. Manufacturing ALWA (a) Pan Granulator machine (b) Pelletizing Process (c) Metakaolin ALWA

Several physical properties tests were performed on ALWA to find out the material properties of ALWA, i.e. to determine setting time, bulk density, water

Table 1. Composition between Metakaolin and Alkali Activator

\begin{tabular}{|c|c|c|c|c|c|c|}
\hline \multirow{3}{*}{$\begin{array}{l}\text { Manufacturing } \\
\text { number }\end{array}$} & \multicolumn{4}{|c|}{ Weight (gram) } & \multicolumn{2}{|c|}{ Precentage (\%) } \\
\hline & \multirow{2}{*}{ Metakaolin } & \multicolumn{3}{|c|}{ Alkali Aktivator } & \multirow{2}{*}{ Metakaolin } & \multirow{2}{*}{ Alkali Alkali Activator } \\
\hline & & Initial & Rest & Use & & \\
\hline 1 & 317 & 660 & 321 & 339 & 48 & 52 \\
\hline 2 & 361 & 643 & 332 & 311 & 54 & 46 \\
\hline 3 & 374 & 666 & 263 & 403 & 48 & 52 \\
\hline 4 & 432 & 660 & 240 & 420 & 51 & 49 \\
\hline 5 & 426 & 645 & 260 & 385 & 53 & 47 \\
\hline 6 & 475 & 660 & 215 & 445 & 52 & 48 \\
\hline 7 & 431 & 627 & 240 & 387 & 53 & 47 \\
\hline 8 & 410 & 653 & 260 & 393 & 51 & 49 \\
\hline 9 & 459 & 570 & 244 & 326 & 58 & 42 \\
\hline 10 & 514 & 664 & 213 & 451 & 53 & 47 \\
\hline 11 & 452 & 662 & 254 & 408 & 53 & 47 \\
\hline 12 & 487 & 668 & 236 & 432 & 53 & 47 \\
\hline Average & 428 & & & 392 & 52 & 48 \\
\hline
\end{tabular}


Table 2. Details of the Specimens

\begin{tabular}{|c|c|c|c|c|c|c|c|c|c|}
\hline \multirow{4}{*}{ Sample Code } & \multicolumn{2}{|c|}{ Composition of Aggregate } & \multicolumn{6}{|c|}{ Number of Specimens } & \multirow{4}{*}{ Total } \\
\hline & $\mathrm{AM}$ & AN & Ten & engt & nsity & Compr & Stre & Density & \\
\hline & \multirow{2}{*}{ (\%) } & \multirow{2}{*}{$(\%)$} & \multicolumn{3}{|c|}{ (day/piece) } & \multicolumn{3}{|c|}{ (day/piece) } & \\
\hline & & & 7 & 14 & 28 & 7 & 14 & 28 & \\
\hline A & 0 & 100 & 3 & 3 & 3 & 3 & 3 & 3 & 18 \\
\hline B & 50 & 50 & 3 & 3 & 3 & 3 & 3 & 3 & 18 \\
\hline $\mathrm{C}$ & 100 & 0 & 3 & 3 & 3 & 3 & 3 & 3 & 18 \\
\hline
\end{tabular}

Description: AM = Metakaolin ALWA; AN = Normal Aggregate

content, water absorption, and abrasion. On the other hand, several test on concrete produced with ALWA, such as slump test, compressive test and tensile splitting strength test were conducted in order to determine mechanical properties of concrete. All tests were conducted according to relevant ASTM standards. The research documentation is presented in Figure 2

Table 3. Mix Design of Concrete

\begin{tabular}{lrcr}
\hline \multirow{2}{*}{ Materials (\%) } & \multicolumn{3}{c}{ Specimen's Code } \\
\cline { 2 - 4 } & $\mathrm{A}$ & $\mathrm{B}$ & \multicolumn{1}{c}{$\mathrm{C}$} \\
\hline Water & 8 & 8 & 8 \\
Cement & 23 & 23 & 23 \\
Coarse Aggregate & 39 & 20 & 0 \\
ALWA & 0 & 20 & 39 \\
Fine Aggregate & 30 & 30 & 30 \\
\hline Total Volume & 100 & 100 & 100 \\
\hline
\end{tabular}

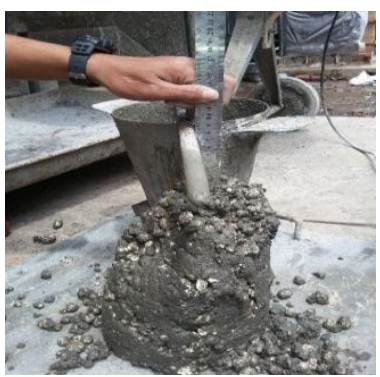

(a)

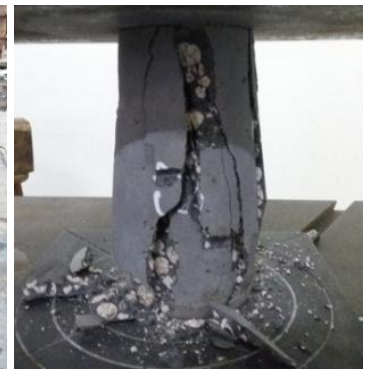

(b)

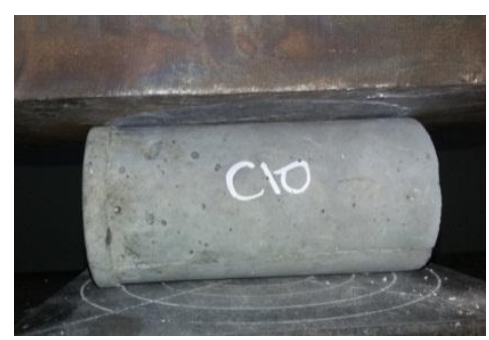

(c)

Figure 2. Research Documentation: (a) Slump Test, (b) Compressive Strength Test; (c) Tensile Splitting Strength Test

\section{Result and Discussion}

\section{Properties of Metakaolin}

The properties of metakaolin ALWA are presented in Table 4.
Table 4. Properties of Metakaolin ALWA

\begin{tabular}{cll}
\hline No & \multicolumn{1}{c}{ Testing } & \multicolumn{1}{c}{ Result } \\
\hline 1 & Setting Time: & \\
& a. initial setting time & 99 minutes \\
& b. final setting time & 130 minutes \\
2 & Water content & $1.20 \%$ \\
3 & Water Absorption & $3.03 \%$ \\
4 & Bulk Density & $939 \mathrm{~kg} / \mathrm{m}^{3}$ \\
5 & Abrasion & $43 \%$ \\
\hline
\end{tabular}

The setting time test was carried out to determine the initial and final setting time of metakaolin paste. The data were required to estimate the hardening time of ALWA during molding process. The test of setting time was carried out in accordance with the guidelines of ASTM C127 [10]. The test result showed that the initial and final setting time of metakaolin paste was 99 minutes and 130 minutes, respectively. These results are in good agreement with Triani et al., who stated that setting time of metakaolin paste was between 60 to 120 minutes [6].

Water content and water absorption tests were performed to determine the water content and the absorption capacity of ALWA in Saturated Surface Dry (SSD) condition. Both tests were performed in accordance with ASTM C127-01 [10]. Based on the test results, the water content and water absorption of metakolin ALWA were found to be $1.25 \%$ and $3.03 \%$, respectively. The water absorption value of metakaolin ALWA produced in this study is lower compared to those reported by Sivakumar, i.e. within a range of $8.9-25.5 \%$ [11]. This different result occurred most probably due to different sintering temperature performed in producing ALWA, where the higher the sintering temperature performed, the higher the number of voids occured, that leads to higher water absorption of ALWA.

The abrasion test was performed to determine the resistance of metakaolin ALWA to abrasion using the Los Angeles abrasion machine in accordance with SNI 2417:200 [12]. The result showed that the abrasion level of metakaolin ALWA was $43 \%$. Thus, it can be predicted that the concrete produced might have low strength. According to ASTM C 535, concrete produced with aggregate which has aggregate abrasion level of $40 \%-50 \%$ is a low quality concrete $(\leq$ $20 \mathrm{MPa}$ ) [13]. 
Metakaolin ALWA has a relatively low bulk density of $939 \mathrm{~kg} / \mathrm{m}^{3}$, lower than gravel which generally has a bulk density of $1450 \mathrm{~kg} / \mathrm{m}^{3}$. With a bulk density below $1000 \mathrm{~kg} / \mathrm{m}^{3}$, metakaolin ALWA is eligible for use as lightweight artificial aggregate in the manufacture of structural lightweight concrete.

\section{Slump Test of Fresh Concrete}

Slump test was performed to measure the workability of fresh concrete and to obtain the uniformity of water use. Slump test was conducted with guidelines from ASTM C143-78 [14]. Slump test results are presented in Table 5. Based on slump test results, it can be seen that sample-C has lower slump value compared to others. This condition is mostly caused by a higher water absorption value of ALWA compared to gravel. With the high water absorption of ALWA, the existing water in the concrete mixture will be absorbed by ALWA and causes the fresh concrete to be thicker and has low slump value. Similarly, Nadesan and Dinakar stated that increasing ALWA levels in concrete mixtures would decrease the workability of fresh concrete due to its high water absorbtion [15]. They advised that using ALWA as coarse aggreagtes should be in SSD condition to reduce the possibility of absorbing water from concrete.

Table 5. Slump Value of Fresh Concrete

\begin{tabular}{crrc}
\hline \multirow{2}{*}{ Sample Code } & \multicolumn{2}{c}{ Coarse Aggregate Ratio } & Slump Value \\
\cline { 2 - 4 } & \multicolumn{1}{c}{ AM } & AN & $(\mathrm{mm})$ \\
\hline A & $0 \%$ & $100 \%$ & 95 \\
A & $0 \%$ & $100 \%$ & 95 \\
B & $50 \%$ & $50 \%$ & 95 \\
C & $100 \%$ & $0 \%$ & 75 \\
\hline
\end{tabular}

\section{Physical Properties of Concrete}

The test of physical properties carried out in this study was the one to determine the density of the cylindrical concrete specimens. The density of concrete was determined from the average values of three specimens. The mean value of the density test result of each the cylindrical concrete, and is presented in Table 6.
As expected, the results shown in Table 6 indicate that the higher amount of metakaolin ALWA used in making concrete is inversely proportional to the density of the concrete. This is in accordance with previous research by Gonzalez-Corrochano et al. They stated that higher sintering temperature reduces the bulk density of ALWA, and resulting in lower density of concrete produced [16].

\section{Mechanical Properties of Concrete}

The tests of mechanical properties in this study were performed to examine the compressive strength and tensile splitting strength of cylindrical concrete. Compressive and tensile splitting tests were carried out on concrete aged 7, 14, and 28 days. The value of compressive strength and tensile splitting strength of concrete was obtained by averaging the results of three specimens. The insides of the specimens A, B, and $\mathrm{C}$ after the tensile splitting strength testing can be seen in Figure 3, while the compressive strength and tensile splitting strength values are presented in Table 7.

Based on the image of spesimens after tensile splitting test displayed at Figure 3, it can be seen that the amount of ALWA crushed on specimen $\mathrm{C}$ is higher compared to specimen $\mathrm{B}$. The rupture of ALWA in specimen $\mathrm{C}$ was caused by its low strength, which made them crushed even during the concrete making process. The crushed of ALWA during the concrete making process resulting in the decrease of mechanical properties of concrete. This is consistent with the expectation that ALWA which has abrasion value more than $40 \%$ will produce low strength concrete (less than $20 \mathrm{MPa}$ ). Previous research also revealed that the strength of ALWA measured by Aggregate Impact value (AIV) greatly affects the mechanical properties of the resulting concrete [15]. The recommended AIV value for ALWA is less than $30 \%$. With AIV value less than $30 \%$, the chance that ALWA will be crushed during concrete manufacturing process can be minimized [17]. Further research on how to increase the strength of ALWA needs to be performed in order to produce high quality concrete.

Table 6. Test Results of the Density of Cylindrical Concrete Specimens

\begin{tabular}{crrccccc}
\hline & \multicolumn{3}{c}{ Composition of Coarse } & \multicolumn{5}{c}{ Average Value } \\
\cline { 3 - 7 } Sample Code & \multicolumn{2}{c}{ Aggregate } & Diameter & Height & Volume & Weight & Volume Weight \\
\cline { 2 - 7 } & AM & AN & $(\mathrm{cm})$ & $(\mathrm{cm})$ & $\left(\mathrm{cm}^{3}\right)$ & $($ gram $)$ & $\left(\mathrm{kg} / \mathrm{m}^{3}\right)$ \\
$\mathrm{A}$ & $0 \%$ & $100 \%$ & 7.45 & 15.33 & 667.58 & 1480 & 2216 \\
B & $50 \%$ & $50 \%$ & 7.43 & 15.28 & 662.20 & 1377 & 2080 \\
$\mathrm{C}$ & $100 \%$ & $0 \%$ & 7.45 & 15.68 & 684.19 & 1260 & 1841 \\
\hline
\end{tabular}

Description: $\mathrm{AM}=$ Metakaolin ALWA; AN = Normal Aggregate 
Table 7. Testing Results of the Compressive Strength and Split Tensile Strength of Specimens

\begin{tabular}{|c|c|c|c|c|c|c|c|c|}
\hline \multirow{3}{*}{$\begin{array}{l}\text { Sample } \\
\text { Code }\end{array}$} & \multirow{2}{*}{\multicolumn{2}{|c|}{$\begin{array}{c}\text { Composition of Coarse } \\
\text { Aggregate }\end{array}$}} & \multicolumn{6}{|c|}{ Average Mechanical Strength of Specimen } \\
\hline & & & \multicolumn{3}{|c|}{ Day/ Compressive Strength (MPa) } & \multicolumn{3}{|c|}{ Day/ Split Tensile Strength (MPa) } \\
\hline & $\mathrm{AM}$ & $\mathrm{AN}$ & 7 & 14 & 28 & 7 & 14 & 28 \\
\hline $\mathrm{A}$ & $0 \%$ & $100 \%$ & 20.98 & 23.03 & 31.16 & 3.44 & 3.36 & 3.47 \\
\hline $\mathrm{B}$ & $50 \%$ & $50 \%$ & 17.26 & 21.07 & 22.52 & 2.29 & 1.67 & 3.18 \\
\hline $\mathrm{C}$ & $100 \%$ & $0 \%$ & 8.94 & 12.24 & 18.55 & 3.13 & 2.52 & 3.23 \\
\hline
\end{tabular}

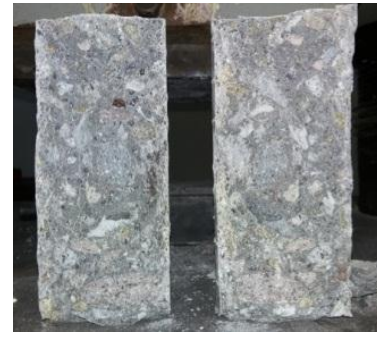

(a)

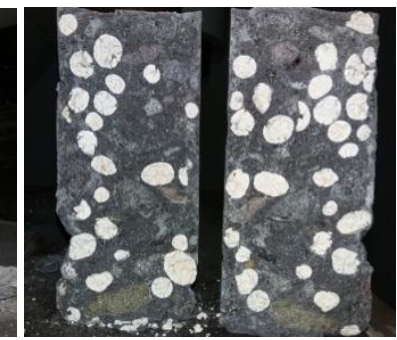

(b)

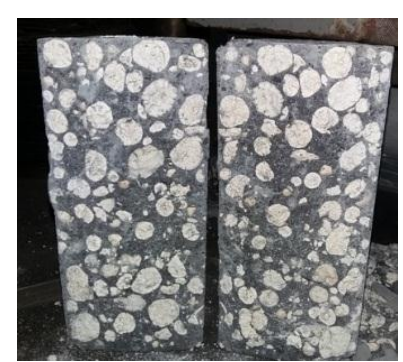

(c)

Figure 3. Photos of Specimens after the Tensile Splitting Tests (a) Specimen A (0\% ALWA), (b) Specimen B (50\% ALWA), (c) Specimen C (100\% ALWA).

The decrease of the compressive strength of concrete specimens with 50\% and 100\% metakaolin ALWA, compared to the one with $0 \%$, are $8.6 \mathrm{MPa}(28 \%)$ and $12.6 \mathrm{MPa}(40 \%)$, respectively. It can be concluded that the amount of metakaolin ALWA used is inversely proportional to the concrete compressive strength. The higher the amount of metakaolin ALWA used in the mixture, the lower the resulting compressive strength.

As predicted, increasing the amount of ALWA in concrete mixture decreases the density of the concrete, which results in decrease of mechanical properties of concrete. However, based on concrete compressive strength and density test results, the specimen $\mathrm{C}$ meets the qualification as a lightweight structural concrete, because it has a density of less than $2000 \mathrm{~kg} / \mathrm{m}^{3}$ and has a compressive strength above $17 \mathrm{MPa}$ [4]. Based on this result, it can be concluded that metakaolin ALWA is a promising alternative lightweight aggregates to produce lightweight structural concrete. Previous research by Yliniemi et al. also revealed that geopolymer aggregates have better physical properties compared to commercial lightweight expanded clay aggregates [18].
There was no significant difference in the values of the tensile splitting strength among the concrete specimens utilizing different aggregates. In other words, the use of metakaolin ALWA as coarse aggregates does not affect the value of tensile splitting strength of concrete. This result has a good agreement with previous research conducted by Beushausen and Dittmer, which investigated the influence of the aggregate type on strength of the concrete [19]. Beushausen and Dittmer stated that the coarse aggregate type did not significantly affect the tensile strength of the concrete. Another report by Gomathi and Sivakumar also stated that tensile splitting strength is more dependant on mortar rather than aggregate type, due to the development of maximum diametral tension on concrete [20].

\section{Correlation Between Split Tensile and Com- pressive Strength}

The relationship between compressive strength and tensile splitting strength of concrete is presented in Table 6. It can be seen that the pattern formed by the tensile splitting strength is stable. The compressive strength of sample B compared to C increased by $3.96 \mathrm{MPa}(21 \%)$ and that of sample B compared to A decreased by $8.65 \mathrm{MPa}$ (38\%). The tensile strength of sample $\mathrm{B}$ compared to $\mathrm{C}$ increased by only 0.05 $\mathrm{MPa}$ and that of sample B compared to A decreased by $0.29 \mathrm{MPa}$. These results indicate that the value of tensile splitting strength is not directly proportional to the value of compressive strength of concrete.

The empirical formula to determine the tensile splitting strength derived from the relationship between the tensile splitting strength and the compressive strength of concrete produced in this study was fct $=0.68 \sqrt{ } \mathrm{fc}^{\prime}$, while the ratio between tensile splitting strength and compressive strength of concrete was in range of 0.1-0.17. A review on the performance of structural concrete utilizing ALWA aggregates conducted by Nadesan and Dinakar summarized that the ratio between tensile splitting strength and compressive strength of concrete with fly ash ALWA is in the range of 0.05-0.12 [15]. The ratio between tensile splitting strength and compressive strength of concrete using metakaolin ALWA aggregates is similar to those of fly ash ALWA aggregates. 
Table 8. Correlation between Compressive Strength and Tensile Splitting Strength

\begin{tabular}{|c|c|c|c|c|}
\hline \multirow{3}{*}{$\begin{array}{c}\text { Sample } \\
\text { Code }\end{array}$} & \multirow{2}{*}{\multicolumn{2}{|c|}{$\begin{array}{c}\text { Composition of } \\
\text { Coarse Aggregates }\end{array}$}} & \multirow{3}{*}{$\begin{array}{l}\text { Compressive } \\
\text { Strength } \\
\text { (MPa) }\end{array}$} & \multirow{3}{*}{$\begin{array}{c}\text { Tensile Splitting } \\
\text { Strength } \\
(\mathrm{MPa})\end{array}$} \\
\hline & & & & \\
\hline & $\mathrm{AM}$ & $\mathrm{AN}$ & & \\
\hline A & $0 \%$ & $100 \%$ & 31.16 & 3.47 \\
\hline B & $50 \%$ & $50 \%$ & 22.52 & 3.18 \\
\hline $\mathrm{C}$ & $100 \%$ & $0 \%$ & 18.55 & 3.23 \\
\hline
\end{tabular}

Description:

$\mathrm{AM}=$ Metakaolin ALWA; AN = Normal Aggregate

\section{Conclusion}

The dosage level of metakaolin ALWA used in concrete mixture composition is inversely proportional to the resulting concrete density. The higher the amount of metakaolin ALWA used in the concrete mixture, the lower the resulting density. The density acceptable for lightweight concrete, i.e. less than $1850 \mathrm{~kg} / \mathrm{m}^{3}$, could only be achieved by using only metakaolin ALWA as the coarse aggregates, without using any normal aggregates.

The amount of metakaolin ALWA used as coarse aggregates is inversely proportional to the value of concrete compressive strength. The higher the amount of metakaolin ALWA used in the mixture, the lower the resulting compressive strength of concrete. The concrete specimens using metakaolin ALWA as coarse aggregates with replacement level of $0 \%, 50 \%$, and $100 \%$ produced concrete with compressive strength of $31.2,22.5$, and $18.6 \mathrm{MPa}$, respectively. These values are acceptable for structural concrete, i.e. more than $17 \mathrm{MPa}$. On the other hand, the use of metakaolin ALWA as coarse aggregates does not significantly affect the value of tensile splitting strength of concrete.

Based on the research results, concrete utilizing $100 \%$ metakaolin ALWA as coarse aggregates produces concrete with density of $1841 \mathrm{~kg} / \mathrm{m}^{3}$ and compressive strength of $18.55 \mathrm{MPa}$. It meets the criteria for structural lightweight concrete in accordance to SNI 03-2461-2002, i.e. the concrete density shall not exceed $1850 \mathrm{~kg} / \mathrm{m}^{3}$ with a compressive strength of not less than $17 \mathrm{MPa}$ [21].

\section{References}

1. Bird, P., An Updated Digital Model of Plate Boundaries, Geochemistry, Geophysics, Geosystems, 4(3), 2003, doi:10.1029/2001GC000252.

2. Tim Revisi Peta Gempa Indonesia, Ringkasan Hasil Studi Tim Revisi Peta Gempa Indonesia. BNPB, Australia-Indonesia Facility for Disaster Education, RISTEK, Departemen PU, ITB, BMKG, LIPI, KESDM, 2010.
3. SNI 1726-2012, Tata Cara Perencanaan Ketahanan Gempa untuk Struktur Bangunan Gedung dan Non-Gedung, Badan Standardisasi Nasional, 2012.

4. Mindess, S and Young, J.F., Concrete, PrenticeHall, 1981.

5. Kementerian Energi dan Sumber Daya Mineral Badan Geologi Pusat Sumber Daya Geologi, Executive Summary Pemutakhiran Data dan Neraca Sumber Daya Mineral Status 2015, 2015.

6. Triani, D.N.D., Ekaputri, J.J., Triwulan, Hardono, S., and Susanto, T.E., Application of Pozzolan as Materials of Geopolymer Paste, Materials Science Forum, 841(111), 2016, pp. 111-117.

7. Risdanareni, P., Puspitasari, P., Santoso, E., and Adi, E.P., Mechanical and Physical Properties of Metakaolin-based Geopolymer Paste, MATEC Web of Conferences,101(1021), 2017.

8. Aineto, M., Acosta, A.,Rincón, J.M., and Romero, M., Production of Lightweight Aggregates from Coal Gasification Fly Ash and Slag, World of Coal Ash (WOCA), Lexington, Kentucky, USA, April 11-15, 2005,

9. Lauw, C.G.S and Buen, S., Beton Ringan NonStruktural dengan Agregat Styrofoam Bekas, Hibah Monodisiplin, LPPM Universitas Katolik Parahyangan, 2014.

10. ASTM C127, Standard Test Method for Density, Relative Density (Specific Gravity), and Absorption of Coarse Aggregate, 2004.

11. Sivakumar, A. and Gomathi, P., Review of Pelletized Fly Ash Lightweight Aggregate Concrete: A Promising Material, Journal of Civil Engineering and Construction Technology, 3(2), 2012, pp. 42-48.

12. SNI 2417:2008, Cara Uji Keausan Agregat dengan Mesin Abrasi Los Angeles, 2008.

13. ASTM C535-16, Standard Test Method for Resistance to Degradation of Large-Size Coarse Aggregate by Abrasion and Impact in the Los Angeles Machine, 2015.

14. ASTM C143-78, Standard Test Method for Slump of Portland Cement Concrete, 2007.

15. Nadesan, M.S. and Dinakar,P., Structural Concrete using Sintered Fly Ash Lightweight Aggregate: A Review, Construction and Building Materials, 154, 2017, pp. 928-944.

16. Gonzalez-Corrochano, B., Alonso-Azcarate, J., and Rodas, M., Effect of Thermal Treatment on the Retention of Chemical Elements in the Structure of Lightweight Aggregates Manufactured from Contaminated Mine Soil and Fly Ash, Construction and Building Materials, 53(91), 2014, pp. 497-507.

17. Terzic, A., Pezo, L., Mitić,V., and Radojevića, Z., Artificial Fly Ash-based Aggregates Properties Influence on Lightweight Concrete Performances, Ceramics International, 41, 2015, pp. 27142726. 
18. Yliniemi, Paiva, Ferreira, V.M., Tiainen, and Illikainen, Development and Incorporation of Lightweight Waste-based Geopolymer Aggregate in Mortar and Concrete, Construction and Building Materials, 131(71), 2017, pp. 132-139.

19. Beushausen, $H$ and Dittmer, T., The Influence of Aggregate Type on Strength and Elastic Modulus of High Strength Concrete, Construction and Building Materials, 74, 2015, pp. 132-139.
20. Gomathi, P. and Sivakumar, A., Accelerated Curing Effects on the Mechanical Performance of Cold Bonded and Sintered Fly Ash Aggregate Concrete, Construction and Building Materials, 77, 2015, pp. 276-287.

21. SNI 03-2461-2002, Spesifikasi Agregat Ringan untuk Beton Ringan Struktural, 2002. 